\title{
Simultaneous removal of cesium and strontium using a photosynthetic bacterium, Rhodobacter sphaeroides SSI immobilized on porous ceramic made from waste glass
}

\author{
Ken Sasaki ${ }^{1 *}$, Hiroyo Morikawa ${ }^{2}$, Takashi Kisibe ${ }^{1}$, Kenji Takeno ${ }^{1}$, Ayaka Mikami ${ }^{3}$, Toshihiko Harada ${ }^{4}$, \\ Masahiro Ohta ${ }^{3}$ \\ ${ }^{1}$ Materials Science and Engineering, Graduate School of Engineering, Hiroshima Kokusa Gakuin University, Hiroshima, Japan \\ ${ }^{2}$ Meisui-Bio Research Institute, Hiroshima Kokusai Gakuin University, Hiroshima, Japan \\ ${ }^{3}$ Ohta-Kokan Co. Ltd., Hiroshima, Japan \\ ${ }^{4}$ Relation Creative Office Co. Ltd., Hiroshima, Japan \\ Email: ${ }^{\text {sasaki@hkg.ac.jp }}$
}

Received 17 October 2012; revised 30 November 2012; accepted 11 January 2013

\begin{abstract}
This study investigated practical and simultaneous removal of cesium (Cs, initial concentration of $5 \mathrm{mg} / \mathrm{L}$ ) and strontium ( $\mathrm{Sr}$, initial concentration of $5 \mathrm{mg} / \mathrm{L}$ ) using a photosynthetic bacterium, Rhodobacter sphaeroides SSI, immobilized on recovery-type porous ceramic made from glass waste. When 4 - 8 pieces/L of SSI immobilized ceramic were added to synthetic sewage wastewater containing glucose, almost $100 \%$ of Cs and $57 \%-61 \%$ removal of Sr was observed after 3 days' aeration treatment. The high potassium (K) concentration in wastewater suppressed Cs removal, but did not affect Sr removal. Other substrates such as lactic, acetic, and propionic acids were useful for $\mathrm{Cs}$ and $\mathrm{Sr}$ removal. But, removal efficiencies were lower than about $50 \%$. When the practical outdoor removal experiment carried out using $1 \mathrm{~m}^{3}$ vessel, almost $100 \%$ of $\mathrm{Cs}$ and $51 \%$ of $\mathrm{Sr}$ were removed like a laboratory experiment after 3 days' aerobic treatment. After treatment, the SSI immobilized ceramic was recovered easily from water using an electromagnet. This SSI immobilized ceramic seem to remove radioactive $\mathrm{Cs}$ and $\mathrm{Sr}$ from water environments of Fukushima, Japan.
\end{abstract}

Keywords: Cs and Sr Removal; Photosynthetic Bacteria; Immobilization; Ceramic Made from Waste Glass;

Recovery Type-Ceramic

\section{INTRODUCTION}

Radionuclide pollution in drinking and agricultural water, sediment mud, soil caused by the discharge of Depleted Uranium (DU) in the Iran-Iraq War and the Gulf War is

${ }^{*}$ Corresponding author. causing severe health problems among local inhabitants [1]. We have been studying removal of radionuclides such as uranium (U), strontium ( $\mathrm{Sr}$ ), and cobalt (Co) using a photosynthetic bacterium, Rhodobacter sphaeroides SSI immobilized on porous ceramic for more than 10 years [2]. These immobilized cells can remove almost $100 \%$ of toxic metals of $20 \mathrm{mg} / \mathrm{L}$ in synthetic sewage wastewater such as mercury $(\mathrm{Hg})$, chromium $(\mathrm{Cr})$ and cadmium $(\mathrm{Cd})$ after 2 - 5 days' treatment [2,3]. Arsenate (As) of $2 \mathrm{mg} / \mathrm{L}$ in the wastewater removed $100 \%$ after 2 day's treatment [2]. Strain SSI can adsorb cations such as positively charged radionuclides and toxic metals using extracellular polymeric substances (EPS) produced on cell surfaces. The EPS have a negative charge and attract cations to the cell surface [2,3]. Moreover, SSI immobilized ceramic, which contains iron, can be recovered using electromagnets. Thereby, radionuclides can be removed easily from water, sediment mud, and soil. From a practical perspective, this method is particularly advantageous for removal of radioactive and toxic metals from polluted water environments [2,3].

The March 2011 nuclear accident at the Fukushima Daiichi Power Plant and subsequent wide diffusion of radioactive materials into the environment contaminated the area's soil, water, and sediment mud with radioactive materials. This water, sediment mud, and soil must be purified. Rapid treatment is necessary to recover from this disaster affecting Japan's Tohoku region. Because of its short half life (about 8.0 days), ${ }^{137} \mathrm{I}$ has become less dangerous in the area. The main radionuclides removed from water and sediment mud in summer 2011 in Fukushima City were Cs and a small amount of $\mathrm{Sr}$.

Removal of radioactive Cs from polluted water has been conducted mainly using physical approaches such as adsorption by zeolite, clay, and chemicals [4-6]. Ad- 
vantages of using zeolite and clay are simple and convenient, but the amount of radioactive waste which adsorbed radioactive cesium is huge and temporal stock place are limited in Fukushima area. Adsorption by chemicals such as iron ferro-cyanide is rather complex process and need high cost. Chemical treatment using solvents has also been proposed [7]. Extraction by crown ether solvent is effective for radioactive cesium, however, high cost and safety of solvent itself for agricultural field and environment become the new problem. Therefore, more efficient, more convenient, safety and less expensive technologies must be developed for practical use.

Regarding the biological removal of radioactive $\mathrm{Cs}$, Haselwandter and Berreck [8] investigated radioactive Cs accumulation by the fungus Paxillus involutus. Avery et al. [9] reported $\mathrm{Cs}$ accumulation by cyanobacterium Synechocystis PCC 6803. Tomioka et al. [10] reported Cs accumulation by Rhodococcus erythropolis and Rhodococcus sp. We applied radioactive Cs removal from the water and sediment mud of swimming pool in Fukushima City during August-October, 2011 and succeeded in removal of about $90 \%$ of radioactive Cs using alginate-immobilized SSI beads [11]. Strain SSI is a spontaneous mutant of Rhodobacter sphaeroides $\mathrm{S}$ which is an anoxygenic photosynthetic bacterium grown under anaerobic-light and aerobic-dark conditions with relatively high growth rate and high chemical oxygen demand (COD) reduction. Strain S is frequently used for practical wastewater treatment from food industries under dark-aerobic treatment without light illumination $[2,11]$. However, simultaneous Cs and Sr removal using strain SSI has not been reported to date. In addition, alginate-immobilization to beads [11] and recovery-type porous ceramic [2] we have used are rather expensive for practical use. We therefore sought to produce SSI immobilized porous glass ceramics inexpensively using discharged waste glass.

As described herein, simultaneous removal of nonradioactive $\mathrm{Cs}$ and $\mathrm{Sr}$ was investigated using SSI immobilized ceramic produced from waste glass on a laboratory scale. Furthermore, practical outdoor experiments for $\mathrm{Cs}$ and $\mathrm{Sr}$ removal were conducted using a $1 \mathrm{~m}^{3}$ vessel considering practical application.

\section{MATERIALS AND METHODS}

\subsection{Microorganism and Culture Conditions}

The photosynthetic bacterium, Rhodobacter sphaeroides SSI, is a spontaneous mutant of Rhodobacter sphaeroides S [2] with self-flocculating ability to produce EPS on the surface of cells. For cultivation of strain SSI, glutamate-malate (GM) medium was used [2,3]. We observed that potassium $(\mathrm{K})$ in the cells suppresses Cs adsorption during prior experiments [11]. Therefore, we used Kdeficient cells grown with low-K concentrations of GM medium containing half the amount of K. A 1.5-L Roux bottle containing $1 \mathrm{~L}$ of GM medium was used for cultivation under static light conditions (5 klux, $20 \mathrm{~W} / \mathrm{cm}^{2}$ ) with a tungsten bulb at $30^{\circ} \mathrm{C}$ for 3 days [2,3]. Strain SSI is a facultative aerobic bacterium that can grow rapidly under either anaerobic-light (photosynthesis) or aerobicdark (respiration) conditions [2,3].

\subsection{Electromagnet Recovery-Type Porous Ceramic Made from Glass Waste}

For radionuclide removal from water, we used a recovery-type porous ceramic produced originally by Nagao Co. Ltd., Okayama, Japan [2]. This ceramic can be recovered using an electromagnet after removing radio-nuclides and toxic metals from water, sediment mud, and soils. However, it must be manually produced and because it is unsuitable for mass production, this ceramic is rather expensive.

As described herein, we used a commercial porous ceramic (Super Sol L1; CoCo Co. Ltd., HigashiHiroshima, Japan) produced from glass waste for use as a material for construction, civil engineering projects, agriculture, and gardening. This ceramic, with small block pieces used here, is presented in Figure 1 as 4 - 5 $\mathrm{cm}$ length. Its characteristics are as follows: about $1-\mathrm{mm}$ pore size, obvious specific gravity of about 0.4 , and water absorbance of about $10 \%$. Its components are $\mathrm{SiO}_{2}$ (71.0\%), $\mathrm{CaO}$ (10.9\%), $\mathrm{Na}_{2} \mathrm{O}$ (13.2\%), $\mathrm{Al}_{2} \mathrm{O}_{3}$ (1.76\%), $\mathrm{K}_{2} \mathrm{O}(1.11 \%)$, and $\mathrm{MgO}(0.2 \%)$. We improved this

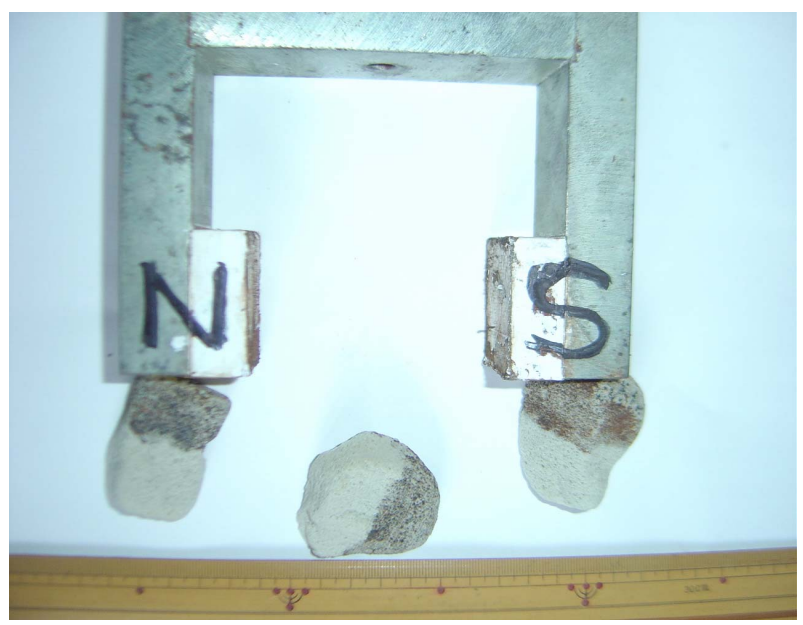

Figure 1. Recovery type of porous ceramic carrier made from waste glass. In the porous ceramic block, one part, shown as black moiety contains $5 \%$ iron for recovery by electromagnet (expressed as N and S). Photosynthetic bacterium, Rhodobacter sphaeroides SSI immobilized ceramic was recovered from water, soil and sediment mud using electromagnet after Cs and Sr removal treatment. 
ceramic to magnetic recovery type ceramic using iron and a binder solution. One part of the ceramic soaked in iron containing binder and incinerated at about $900^{\circ} \mathrm{C}$ using the same procedure described in a previous report [2].

\subsection{Immobilization of SSI Cells}

After cultivation of SSI, cells were harvested by centrifugation $(10,000 \times \mathrm{g}, 20 \mathrm{~min})$ and concentrated to OD660 $=25$ (cell dry weight $12.5 \mathrm{~g} / \mathrm{L}$ ) with deionized water. This high-density cell broth was mixed with $4 \%$ sodium alginate with equal volume (1:1). The piece of porous ceramic was subjected to decompression by an aspirator and poring of the SSI cells and alginate broth to incorporate the cells within the ceramic interior. Subsequently these pieces of ceramic were soaked for $12 \mathrm{hr}$ in $2 \% \mathrm{CaCl}_{2}$ solution for complete immobilization using the same procedure as that described in a previous report [2]. One piece of SSI immobilized ceramic contains about $0.053 \mathrm{~g}$ dry cells ( $1.5 \mathrm{~g}$ wet cells).

\subsection{Indoor Laboratory Experiments for the Removal of Cs and Sr}

To remove Cs and Sr simultaneously, the SSI immobilized ceramic $(4-8$ pieces $)$ was put in a $1.5 \mathrm{~L}$ polyethylene vessel $(15 \times 10 \times 7 \mathrm{~cm})$ with a lid. One liter of synthetic sewage wastewater $(\mathrm{g} / \mathrm{L}$ tap water: $\mathrm{D}$ glucose 4.0, $\mathrm{NaHPO}_{4} 0.06, \mathrm{NH}_{4} \mathrm{Cl} 0.117, \mathrm{MgSO}_{4} \cdot 7 \mathrm{H}_{2} \mathrm{O}$ 0.056 , peptone 0.15 , and $\mathrm{KH}_{2} \mathrm{PO}_{4} 0$ - 0.026) was placed in the vessel along with $4-8$ pieces of immobilized ceramic. Lactic acid $(4 \mathrm{~g} / \mathrm{L})$ and sodium acetate $\left(\mathrm{CH}_{3} \mathrm{COONa}\right.$, $2.78 \mathrm{~g} / \mathrm{L})$ and sodium propionate $\left(\mathrm{C}_{2} \mathrm{H}_{5} \mathrm{COONa}, 2.63 \mathrm{~g} / \mathrm{L}\right)$ $(2 \mathrm{~g} / \mathrm{L}$ of acetic and propionic acids, total $4 \mathrm{~g} / \mathrm{L}$ of acids) were also used in place of glucose as synthetic wastewater. Contents were subjected to sterile air aeration with a $0.25 \mu \mathrm{m}$ filter with $0.2-0.5 \mathrm{vvm}$ at $30^{\circ} \mathrm{C}$ for 5 days. A round sparger for fish culture was used as the nozzle. Only four pieces of porous ceramic without SSI cells were used in the control experiment. The liquid $\mathrm{pH}$ was adjusted every day to $6.0-7.5$ manually with $6 \mathrm{~N} \mathrm{HCl}$ and $6 \mathrm{~N} \mathrm{NH}_{4} \mathrm{OH}$. Then $5-10 \mathrm{mg} / \mathrm{L}$ of non-radioactive $\mathrm{Cs}$ and $\mathrm{Sr}\left(\right.$ as $\mathrm{CsCl}_{2}$ and $\mathrm{SrCO}_{3}$ ) was added to the vessel. After 4 - 5 days' treatment, the SSI immobilized ceramic was recovered using an electromagnet floating on the water surface. However, almost $98 \%-100 \%$ of the block moiety was soaked in the water.

\subsection{Outdoor Experiment for Removal of Cs and $\mathrm{Sr}$}

A $1-\mathrm{m}^{3}$ polyethylene vessel was used for outdoor experiments. SSI immobilized ceramic was put in a mesh bag $(1.0 \times 1.0 \mathrm{~cm}$ mesh, $15 \mathrm{~cm}$ diameter, and $30 \mathrm{~cm}$ length). We prepared 1200 - 1700 pieces of SSI immobilized ceramic and divided it into 10 mesh bags.

These 10 mesh bags were put in $500 \mathrm{~L}$ of synthetic wastewater containing $5 \mathrm{mg} \mathrm{Cs}$ and $\mathrm{Sr}$, as described before in $1 \mathrm{~m}^{3}$ vessel. Then aeration of $0.2-0.5 \mathrm{vvm}$ (without sterilization) was continued for 4 days. The substrate of synthetic wastewater was D-glucose $(4 \mathrm{~g} / \mathrm{L})$ and DL-lactic acid $(4 \mathrm{~g} / \mathrm{L})$. The broth $\mathrm{pH}$ was maintained manually as $6.0-7.5$ every day, as described before. The temperature was $21^{\circ} \mathrm{C}-25^{\circ} \mathrm{C}$, corresponding to the laboratory outdoors. SSI immobilized ceramic can be recovered by electromagnets on the water surface, but we had no large electromagnet. Therefore, a mesh bag was used here for the recovery of ceramic blocks in this outdoor experiment.

\subsection{Analysis}

$\mathrm{Cs}$ and $\mathrm{Sr}$ in synthetic wastewater was measured using supernatant after centrifugation $(10,000 \times \mathrm{g}, 20 \mathrm{~min})$ and supernatant was decomposed with $\mathrm{HNO}_{3}$ (the final concentration was $0.1 \%$ ) and subjected to inductively coupled plasma atomic emission spectroscopy (ICP-AES) analyzer (SPS 3100; SIS Co. Ltd., Tokyo, Japan). For Cs analysis, $250 \mathrm{~m} \mathrm{~g} / \mathrm{L}$ of $\mathrm{CoCl}_{2}$ in ammonium acetate solution $(1 \mathrm{M})$ was added into the liquid after decomposition using $\mathrm{HNO}_{3}$ to remove the interruption of $\mathrm{Na}$ and other cationic ions. Atomic absorption (AA) analysis (AA-6200; Shimadzu Co. Ltd., Kyoto, Japan) was also used for analysis of Cs at low concentrations (less than 2 $\mathrm{mg} / \mathrm{L}$ ) to confirm the analyses by ICP-AES using the same solution. Almost identical results were obtained between ICP-AES and AA analyses. The lower limit of detection of Cs and Sr by ICP-AES were $2 \mathrm{mg} / \mathrm{L}$ and 0.1 $\mu \mathrm{g} / \mathrm{L}$ and those by AA were $10 \mu \mathrm{g} / \mathrm{L}$ and $5 \mu \mathrm{g} / \mathrm{L}$, respectively.

\section{RESULT}

\subsection{Simultaneous Removal of Cs and Sr by SSI Immobilized Ceramic}

Using 4 - 8 pieces of SSI immobilized ceramic per $1 \mathrm{~L}$ of synthetic wastewater, simultaneous removal of $\mathrm{Cs}$ and $\mathrm{Sr}$ was investigated in the indoor incubator $\left(30^{\circ} \mathrm{C}\right)$.

As presented in Figure 2(a), Cs was removed almost $100 \%$ after 3 days with 4 and 8 pieces of SSI immobilized ceramic. This ceramic, which was made from waste glass itself, was not able to adsorb Cs. Because alginate can not adsorb Cs [2,11], SSI cells adsorbed Cs. For Sr removal, 57\% - 61\% removal was observed with 4 - 8 pieces of SSI immobilized ceramic after 3 days, as presented in Figure 2(b). Sr can also not be adsorbed by alginate [2]. Although Sr removal was insufficient, simultaneous removal of $\mathrm{Cs}$ and $\mathrm{Sr}$ was successful using 


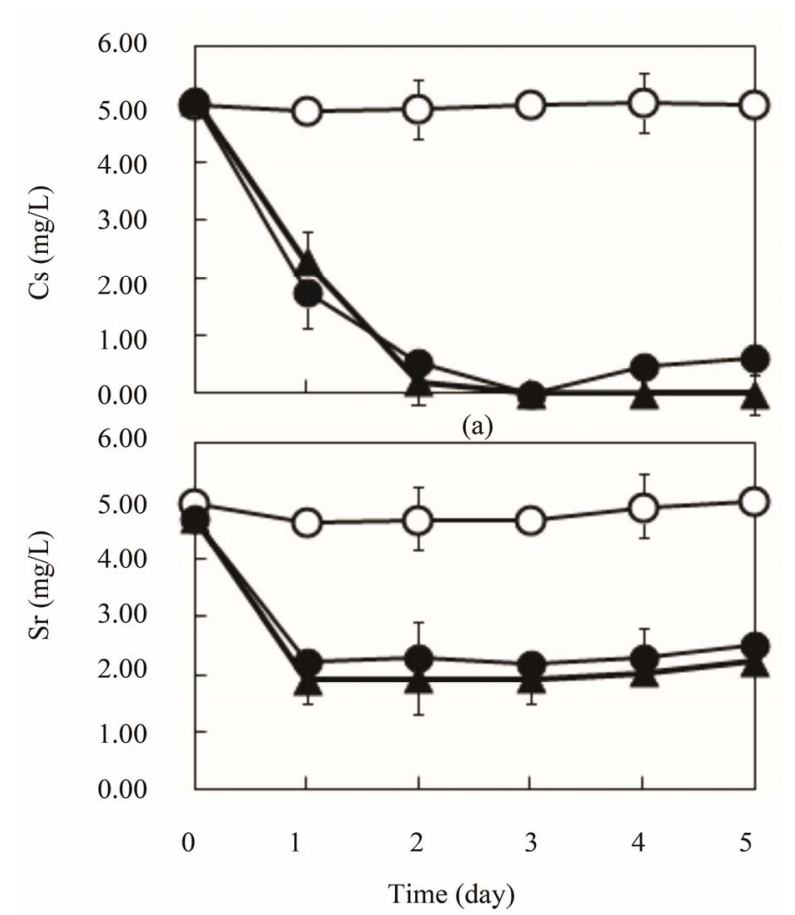

(b)

Figure 2. Cs and Sr removal by $R$. sphaeroides SSI immobilized ceramic in synthetic wastewater of glucose $(4 \mathrm{~g} / \mathrm{L})$ as a substrate. 4 - 8 pieces of SSI immobilized ceramic were put in synthetic wastewater $(\mathrm{K}=1.75 \mathrm{mg} / \mathrm{L})$ in $1 \mathrm{~L}$ vessel and aera- tion $(0.2-0.5 \mathrm{vvm})$ was conducted at $30^{\circ} \mathrm{C}$. (a) Cs (initial, $5 \mathrm{mg} / \mathrm{L}$ ); (b) $\mathrm{Sr}$ (initial, $5 \mathrm{mg} / \mathrm{L}$ ). $\circ$, control (4 pieces of ceramic without SSI cells); $\bullet, 4$ pieces of SSI-immobilized ceramic; $\boldsymbol{\Lambda}, 8$ pieces of SSI immobilized ceramic.

SSI immobilized ceramic made from waste glass. SSI immobilized ceramic was recovered from water easily using an electromagnet. Therefore, results showed that $\mathrm{Cs}$ and $\mathrm{Sr}$ could be removed effectively from water together with SSI immobilized cells and waste glass ceramic.

\subsection{Effects of Potassium on Removal of Cs and $\mathrm{Sr}$}

During preliminary $\mathrm{Cs}$ and $\mathrm{Sr}$ removal experiments, Cs removal was not stable (data not shown). Because of the characteristics of the water used for synthetic wastewater, we infer that potassium $(\mathrm{K})$ affects $\mathrm{Cs}$ adsorption on the SSI cells [11]. Jasper [12] reported that Cs was mainly incorporated by the $\mathrm{K}$ transport system of a photosynthetic bacterium, Rhodopseudomonas capsulata. Therefore, we investigated the effects of $\mathrm{K}$ concentration on the removal of Cs and Sr with SSI immobilized ceramic.

As depicted in Figure 3(a), Cs removal was affected by the $\mathrm{K}$ concentration. With high concentrations of $\mathrm{K}$ of $6.70 \mathrm{mg} / \mathrm{L}$, which is the standard concentration of synthtic wastewater, Cs removal was suppressed compared with that of low concentration of K $(0-3.35 \mathrm{mg} / \mathrm{L})$. High concentration of $\mathrm{K}$ was unsuitable for Cs removal, but the $\mathrm{K}$ concentration did not affect $\mathrm{Sr}$ removal (Figure 3(b)).

It was clear that low $\mathrm{K}$ concentration was important for effective Cs removal using SSI immobilized ceramic. In the practical removal of $\mathrm{Cs}$ in Fukushima area, $\mathrm{K}$ concentration in the liquid should be considered for effective Cs removal.

\subsection{Effects of Acetic and Propionic Acids and Lactic Acid for Cs and Sr Removal as the Substrates}

Considering the practical removal of $\mathrm{Cs}$ and $\mathrm{Sr}$, effects of other substrates such as acetic acid, propionic acid, and lactic acid were investigated as less expensive substrates. Such substrates are frequently observed in postanaerobic-digestion liquor including methane fermentation of organic wastes. Thesepost-anaerobic-digestion liquors containing such acids might be applicable to Cs and $\mathrm{Sr}$ removal.

As portrayed in Figure 4, 46\% - 48\% of Cs was removed after 2 - 3 days using mixed substrates of acetic and propionic acids instead of glucose (Figure 4(a)). For Sr removal, similar trends were also observed to those shown in Figure 1(b). When $4 \mathrm{~g}$ lactic acid was used as a substrate of synthetic wastewater instead of glucose,

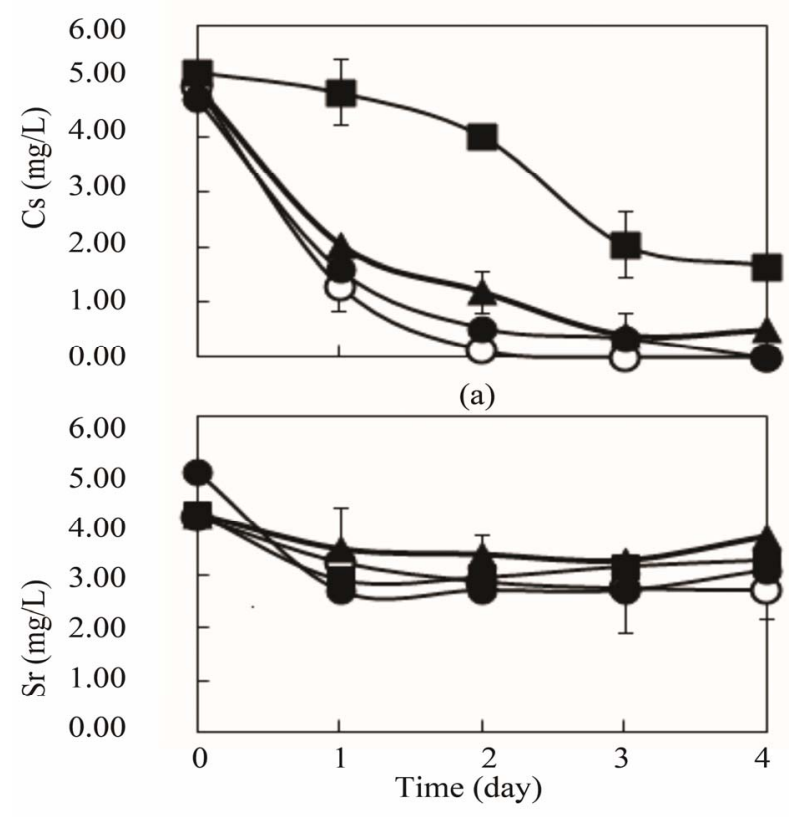

(b)

Figure 3. Effect of $\mathrm{K}$ concentration on removal of $\mathrm{Cs}$ and $\mathrm{Sr}$ by $R$. sphaeroides SSI immobilized ceramic in the synthetic wastewater of glucose $(4 \mathrm{~g} / \mathrm{L})$ as a substrate. 4 pieces of SSI immobilized ceramic were put in $1 \mathrm{~L}$ synthetic sewage wastewater. Then aeration $(0.2-0.5 \mathrm{vvm})$ was conducted at $30^{\circ} \mathrm{C}$. (a) Cs (initial, $5.0 \mathrm{mg} / \mathrm{L}$ ); (b) Sr (initial, $5 \mathrm{mg} / \mathrm{L}$ );, $\mathrm{K} 0 \mathrm{mg} / \mathrm{L}$; $\bullet, \mathrm{K} 1.75 \mathrm{mg} / \mathrm{L} ; \boldsymbol{\Delta}, \mathrm{K} 3.35 \mathrm{mg} / \mathrm{L} ; \mathbf{m}, \mathrm{K} 6.70 \mathrm{mg} / \mathrm{L}$. 


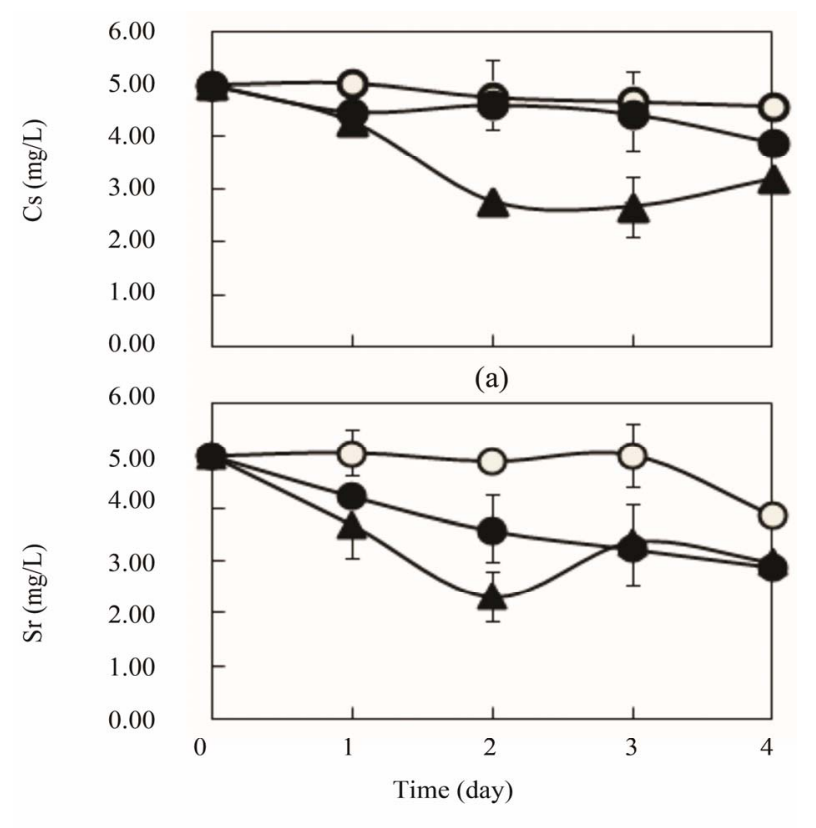

(b)

Figure 4. Cs and Sr removal by $R$. sphaeroides SSI immobilized ceramic in synthetic wastewater of acetic and propionic acids $(2 \mathrm{~g}+2 \mathrm{~g}$, total $4 \mathrm{~g} / \mathrm{L})$ as mixed substrates. $4-8$ pieces of SSI immobilized ceramic were put in synthetic wastewater (K $=1.75 \mathrm{mg} / \mathrm{L})$ in a $1 \mathrm{~L}$ vessel and aeration $(0.2-0.5 \mathrm{vvm})$ was conducted at $30^{\circ} \mathrm{C}$. (a) Cs (initial, $5.0 \mathrm{mg} / \mathrm{L}$ ); (b) $\mathrm{Sr}$ (initial, 5 $\mathrm{mg} / \mathrm{L})$; ○, control, 4 pieces of ceramic without SSI cells; $\bullet, 4$ pieces of SSI immobilized ceramic; $\boldsymbol{\Delta}, 8$ pieces of SSI immobilized ceramic.

almost identical results to those portrayed in Figure 4 were observed (data not shown). Lactic acid is frequently produced from organic wastes by lactic acid fermentation together with acetic acid and propionic acid formation. As inferred from these results, these organic acids have the possibility to use for removal of Cs and Sr.

\subsection{Practical Removal of Cs and Sr in Outdoor Scale-Up Experiment}

In biotechnological processes, even if indoor small-scale (flask level) experiments were successful, it remains uncertain whether these successful results are obtainable again in large practical scale experiments. Only rarely are results in indoor experiments matched by those obtained from outdoor large-scale experiments. Scaledup experiments must be conducted to resolve this problem.

In Figure 5, results of a practical large scale experiment using $1 \mathrm{~m}^{3}$ vessel (500 L liquid) in outdoor are shown when $4 \mathrm{~g} / \mathrm{L}$ of lactic acid was used as a substrate of synthetic wastewater. $45 \%-51 \%$ of Cs were removed after 1 - 3 days, but Cs was not further reduced after 1 day (Figure 5(a)). This result was an almost identical

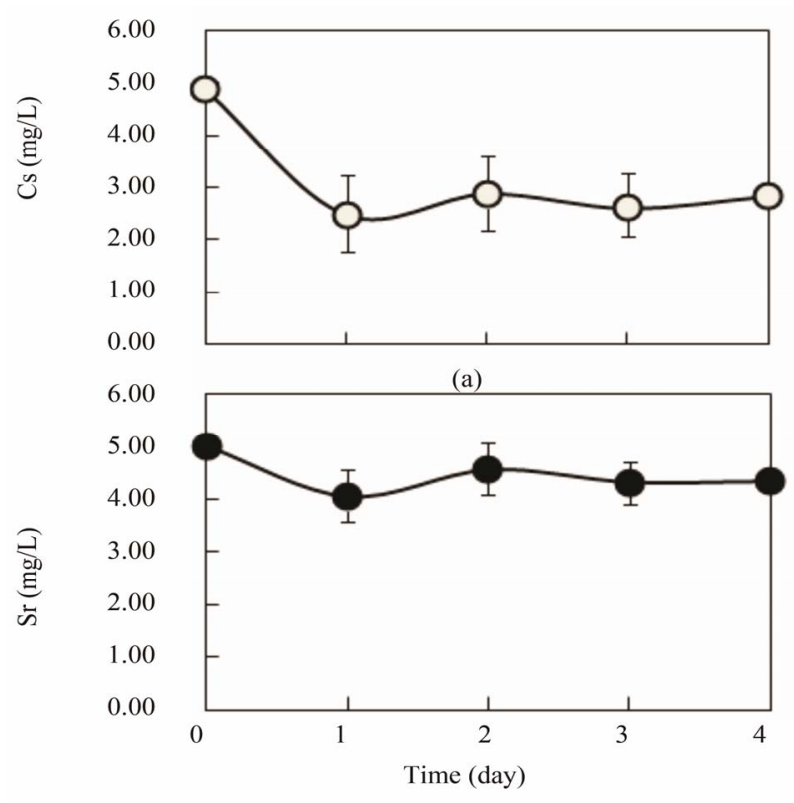

(b)

Figure 5. Outdoor experiments of $\mathrm{Cs}$ and $\mathrm{Sr}$ removal by $R$. sphaeroides SSI immobilized ceramic in synthetic wastewater of lactic acid ( $4 \mathrm{~g} / \mathrm{L})$ as a substrate. 1200 pieces of SSI immobilized ceramic were put in $500 \mathrm{~L}$ sewage wastewater $(\mathrm{K}=1.75$ $\mathrm{mg} / \mathrm{L}$, contained in $1 \mathrm{~m}^{3}$ vessel). Aeration of $0.2-0.5 \mathrm{vvm}$ was conducted. $\mathrm{pH}$ of the water was maintained manually at 6.0 7.5. The outdoor temperature was $21^{\circ} \mathrm{C}-25^{\circ} \mathrm{C}$. (a) Cs (initial, $5.0 \mathrm{mg} / \mathrm{L}$ ); (b) Sr (initial, $5 \mathrm{mg} / \mathrm{L}$ ); $\circ$, Cs concentration in wastewater; $\bullet, \mathrm{Sr}$ concentration in wastewater.

result to those for indoor experiments like the result portrayed in Figure 4. Sr was rather difficult to remove, showing 11\% - 20\% removal after 1 - 4 days (Figure 5(b)). This low efficiencies of Cs and $\mathrm{Sr}$ removal compared with those in glucose substrates were apparently dependent on the differences of substrate and low activity of SSI cells. Lactic acid is not a preferable substrate for SSI cells activity.

However, when glucose was used as synthetic wastewater in an outdoor experiment, almost $100 \%$ Cs and $31 \% \mathrm{Sr}$ were removed after 4 days, as shown in Figures 6(a) and (b), even at low temperatures $\left(21^{\circ} \mathrm{C}-25^{\circ} \mathrm{C}\right)$. Furthermore, when the SSI immobilized ceramic was increased to 1700 pieces $/ 500 \mathrm{~L}$, which corresponds to 3.4 pieces SSI immobilized ceramic/L, almost $100 \%$ of Cs was removed after 2 - 4 days (Figure 6(c)). Sr was reduced 50\% - 51\% after 3 - 4 days (Figure 6(d)). These results were the same results as those obtained for indoor laboratory scale experiments.

\section{DISCUSSION}

Simultaneous removal of Cs and $\mathrm{Sr}$ was achieved using SSI strains immobilized on porous ceramic made from waste glass. The Cs was removed almost $100 \%$ by 4 


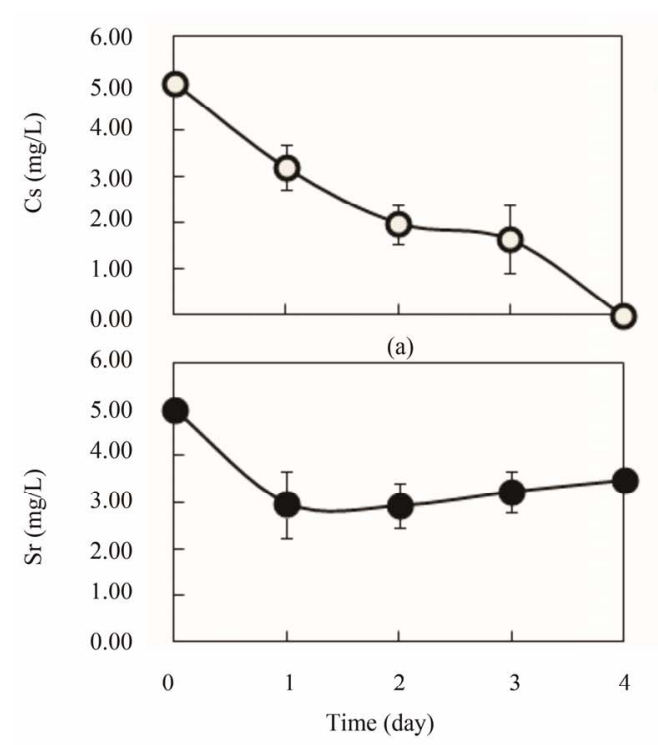

(b)

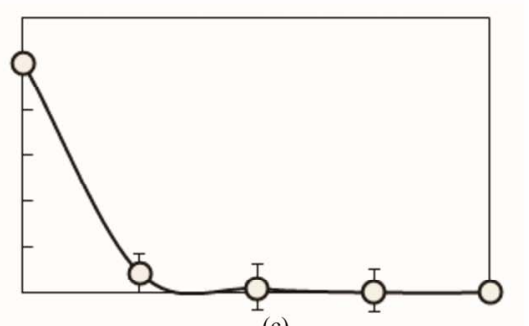

(c)

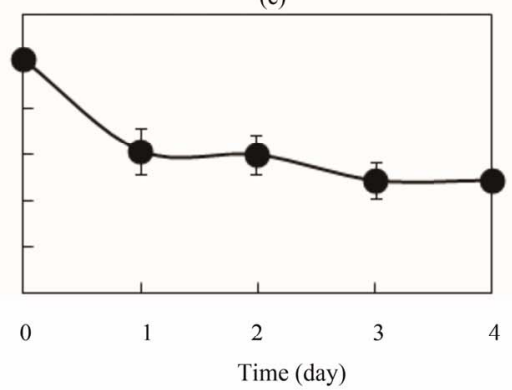

(d)

Figure 6. Outdoor experiment of Cs and Sr removal by $R$. sphaeroides SSI immobilized ceramic in synthetic wastewater of glucose $(4 \mathrm{~g} / \mathrm{L})$ as a substrate. 1200 pieces (a), (b) and 1700 pieces (c), (d) of SSI immobilized ceramic were put in $500 \mathrm{~L}$ of synthetic waste-water $(\mathrm{K}=$ $1.75 \mathrm{mg} / \mathrm{L}$, contained in $1 \mathrm{~m}^{3}$ vessel). (a), (c) Cs (initial, $5.0 \mathrm{mg} / \mathrm{L}$ ); (b), (d) Sr (initial, 5 $\mathrm{mg} / \mathrm{L}) ; \circ$, Cs concentration in wastewater; $\bullet$, Sr concentration in wastewater.

pieces of SSI immobilized ceramic/L synthetic wastewater, and $\mathrm{Sr}$ was removed about $57 \%$ - $61 \%$ after 3 days in indoor experiments. In addition, this simultaneous removal was confirmed in outdoor experiments with a practical level of experimentation using $1 \mathrm{~m}^{3}$ vessel of $500 \mathrm{~L}$ scale. Results of Figure 6 demonstrate advantages for the practical and simultaneous removal of $\mathrm{Cs}$ and $\mathrm{Sr}$ in outdoor treatments. This SSI immobilized ceramic can be used repeatedly at least three times to remove radioactive Cs from sediment mud from school swimming pools in Fukushima City [11]. Therefore, this technology is apparently applicable for the removal of radioactive Cs-polluted water in the Fukushima area.

Recently, Shimura et al. [13] reported radioactive Cs accumulation by the green algae, Parachlorella binos about $40 \%$ radioactive Cs was removed after $10 \mathrm{~min}$. However, no further removal of Cs was observed with highly dense cell concentration $(100 \mathrm{mg}$ wet cell/ $1 \mathrm{ml}$ water) in a flask experiment [13]. Our results were more successful and practical compared to that by Shimura et al.

Lactic, acetic and propionic acids were also used for $\mathrm{Cs}$ and $\mathrm{Sr}$ removal as the substrate (Figures 4 and 5). However, the maximum removal of Cs and $\mathrm{Sr}$ were $48 \%$ and $52 \%$ in the mixed substrates of acetic and propionic acids (Figure 4) and 51\% and 20\% in lactic acid (data not shown), respectively in indoor experiment. These values are lower compared with those in glucose substrate (Figure 1). Such organic acids seem to be possible to apply the practical removal of Cs and Sr. But, removal efficiency of Cs (less than about 50\%) need to improve up to about $70 \%-100 \%$ by adding glucose or other organic substrates as the mixed substrates for practical application. The SSI cells are not active for such organic acids as the substrate compared with glucose. This reason is not elucidated. Energy harvesting system from such substrates may not enough to support the uptake or incorporate of Cs and $\mathrm{Sr}$ by SSI cells.

In outdoor experiment using lactic acid at relatively low temperature at $21^{\circ} \mathrm{C}-25^{\circ} \mathrm{C}$, Cs and $\mathrm{Sr}$ removal were the same level as indoor experiment at $30^{\circ} \mathrm{C}$. It suggests that lactic acid is also not a preferable substrate for SSI cell activity as discussed before. The relatively low temperature seem to not effect so strongly for SSI cell activity. Glucose is a preferable substrate for $\mathrm{Cs}$ and $\mathrm{Sr}$ removal in indoor $\left(30^{\circ} \mathrm{C}\right)$ and outdoor experiment $\left(21^{\circ} \mathrm{C}\right.$ $-25^{\circ} \mathrm{C}$ ). Lactic acid and acetic and propionic acids are cheap substrates, therefore, the combination of glucose and lactic acid or acetic and propionic acids need to consider in practical application to save glucose amount (relatively expensive).

Regarding the mechanism of Cs and Sr removal, we have already speculated on the negative charge of EPS produced on the surface of cells $[2,11]$. However, Jasper [12] reported that Cs uptake by $R$. capusulata is performed mainly by the $\mathrm{K}$ transport system. Our experiment showed that a high concentration of $\mathrm{K}$ suppressed Cs removal, as depicted in Figure 3. This result suggests that the possibility of $\mathrm{K}$ transport system was functioned in Cs removal in SSI cells. The mechanism of $\mathrm{Sr}^{2+}$ re- 
moval by SSI cells is not elucidated. However, adsorption by the negative charge of EPS is speculated like $\mathrm{Cd}^{2+}$ adsorption by EPS of $R$. sphaeroides $\mathrm{S}$ [3]. Adsorption isotherm of $\mathrm{Cd}^{2+}$ was expressed in the Friedrich equation [3].

Our results confirmed the practical and simultaneous removal of Cs and Sr with SSI immobilized ceramic in outdoor experiments. Cultivation of SSI cells is easy and inexpensive. SSI immobilization on ceramic made from waste glass is also easy and inexpensive. In addition, SSI cells can adsorb toxic metals such as $\mathrm{Cr}, \mathrm{Hg}, \mathrm{Cd}$, and As [2]. It is therefore applicable in other fields such as remediation of wastewater from uranium mining or radionuclide pollution by DU in the Iraq or Iran area polluted during the Iran-Iraq War and the Gulf War.

After removal of $\mathrm{Cs}$ and $\mathrm{Sr}$, the $\mathrm{Cs}$ and $\mathrm{Sr}$ adsorbed on ceramic can be eluted from $1 \%-5 \% \mathrm{NaCl}$ solution together with the cells by conversion from gel to sol of alginate $\mathrm{Ca}$ to alginate $\mathrm{Na}$. Sonication treatment enhanced the removal of cells (with Cs and Sr) from the ceramic [2]. The Cs and Sr were eluted into solution and recovered with high concentrated $\mathrm{Cs}$ and $\mathrm{Sr}$ liquid. However, detailed optimum conditions of the amount of $\mathrm{NaCl}$, temperature, time, and sonication power for concentrate of $\mathrm{Cs}$ and $\mathrm{Sr}$ are under investigation considering practical applications.

\section{CONCLUSIONS}

Using a photosynthetic bacterium, Rhodobacter sphaeroides SSI, and porous ceramic made from glass waste that has been modified for recovery using electromagnets, simultaneous removal of $\mathrm{Cs}$ and $\mathrm{Sr}$ from a water environment was investigated on a laboratory scale and on an outdoor practical scale $\left(1 \mathrm{~m}^{3}\right)$, yielding the following results.

1) When 4 - 8 pieces of SSI-immobilized ceramic were added to one $\mathrm{L}$ of synthetic wastewater consisting of glucose as a substrate, almost $100 \%$ of Cs and $57 \%$ $61 \%$ of $\mathrm{Sr}$ were removed simultaneously after 3 days' treatment.

2) Cs removal of SSI-immobilized ceramic was affected by the potassium $(\mathrm{K})$ concentration in synthetic wastewater. Sr removal was unaffected by the K concentration. The low concentration of $\mathrm{K}(0-3.35 \mathrm{mg} / \mathrm{L})$ in synthetic wastewater enhanced $\mathrm{K}$ removal.

3) Lactic, acetic, and propionic acids, which are easily available from anaerobic digestion liquor of organic wastes including methane fermentation, were also applicable substrates for the simultaneous removal of Cs and Sr.

4) In outdoor practical experiments using $1 \mathrm{~m}^{3}$ vessel, simultaneous removal of about $100 \%$ Cs and $50 \%-51 \%$ $\mathrm{Sr}$ was observed after 3 days' treatment when 1700 pieces of immobilized ceramic were used in $500 \mathrm{~L}$ glu- cose synthetic wastewater (corresponding to 3.4 pieces/ $\mathrm{L})$.

5) After treatment, SSI-immobilized ceramic containing $\mathrm{Cs}$ and $\mathrm{Sr}$ were recovered easily from water using electromagnets. SSI-immobilized ceramic is apparently applicable for the practical removal of radioactive Cs and $\mathrm{Sr}$ simultaneously from water environments in the $\mathrm{Fu}-$ kushima area.

\section{REFERENCES}

[1] No DU Hiroshima Project (2006) A world without uranium weapons: The ICBUW challenge, Godo Publishers, Tokyo (in Japanese), 6-158.

[2] Sasaki, K., Hara, C., Takeno, K., Okuhata, H. and Miyasaka, H. (2010) Metals related to radionuclides and heavy metal removal using photosynthetic bacteria immobilized recovery type porous ceramic. Japanese Journal of Water Treatment Boilogy, 46, 119-127.

[3] Watanabe, M., Kawahara, K., Sasaki, K. and Noparatnaraporn, N. (2003) Biosorption of cadmium ions using photosynthetic bacterium, Rhodobacter sphaeroides $\mathrm{S}$ and a marine photosynthetic bacterium, Rhodovulum sp. and their biosorption kinetics. Journal of Bioscience and Bioengineering, 95, 374-378. doi:10.1016/81389-1723(03)80070-1

[4] National Institute of Advanced Industrial Science and Technology (2011) Success in extraction of cesium from the soil using low concentrate acids.

http://www.aist.go.jp/aist.j/press_release/pr2011/pr20110 $\underline{83}$

[5] Sugoh, T. (2012) Present condition of water pollution by radioactive materials and countermeasures. In: Saitoh, K. Ed., The Radioactive Contamination Countermeasures after the Great Eastern Japan Earthquake, NTS Publishers, Tokyo (in Japanese), 161-172.

[6] Takeshita, K. (2012) Development of treatment system for cesium polluted water. In: Saitoh, K. Ed., The Radioactive Contamination Countermeasures after the Great East Japan Earthquake, NTS Publishers, Tokyo (in Japanese), 173-181.

[7] Seko, N., Suzuki, S. and Yasaka, T. (2012) Cesium adsorption effect using high polymer adsorption materials such as crown ether. In: Saitoh, K. Ed., The Radioactive Contamination Countermeasures after the Great East Japan Earthquake, NTS Publishers, Tokyo (in Japanese), 204-210.

[8] Haselwandter, K. and Berreck, M. (1988) Fungi as bioindicators of radiocesium contamination: Pre- and postChernobyl activities. Transactions of the British Mycological Society, 90, 171-174. doi:10.1016/S0007-1536(88)80085-8

[9] Avery, S. V., Codd, G. A. and Gadd, G., M. (1991) Caecations in the cyanobacterium Synechocystis PCC 6803. Journal of General Microbiology, 137, 405-413. doi:10.1099/00221287-137-2-405

[10] Tomioka, N., Utiyama, H. and Yagi, O. (1994) Cesium 
accumulation and growth characteristics of Rhodococcus erythropolis CS98 and Rhodococcus sp. strain CS402. Applied and Environmental Microbiology, 60, 22272231.

[11] Sasaki, K., Morikawa, H., Kishibe, T., Mikami, A., Harada, T. and Ohta, M. (2012) Practical removal of radioactivity from sediment mud in a swimming pool in $\mathrm{Fu}-$ kushima, Japan by immobilized photosynthetic bacteria. Bioscience Biotechnology and Biochemistry, 76, 859-862. doi: $10.1271 / \mathrm{bbb} .110853$
[12] Jasper, P. (1978) Potassium transport system of Rhodopseudomonas capsulata. Journal of Bacteriology, 133, 13141322.

[13] Shimura, H., Itoh, K., Sugiyama, A., Yukawa, K. and Kobayashi, T. (2012) Removal of radioactive materials using micro-green algae "Binos". In: Saitoh, K. Ed., The Radioactive Contamination Countermeasures after the Great East Japan Earthquake, NTS Publishers, Tokyo (in Japanese), 223-228. 